\title{
Chronic Lymphocytic Leukemia B Cells Express Restricted Sets of Mutated and Unmutated Antigen Receptors
}

\author{
Franco Fais, ${ }^{\star}$ Fabio Ghiotto, ${ }^{*}$ Shiori Hashimoto, ${ }^{\star}$ Brian Sellars, ${ }^{*}$ Angelo Valetto, ${ }^{\star}$ Steven L. Allen, ${ }^{*}$ Philip Schulman, \\ Vincent P. Vinciguerra, ${ }^{*}$ Kanti Rai, ${ }^{\ddagger}$ Laura Z. Rassenti, ${ }^{\S}$ Thomas J. Kipps, ${ }^{\S}$ Guillaume Dighiero," Harry W. Schroeder, Jr., \\ Manlio Ferrarini, ${ }^{\star \star}$ and Nicholas Chiorazzi* \\ *Department of Medicine, North Shore University Hospital and New York University School of Medicine, Manhasset, New York 11030; \\ ${ }^{\ddagger}$ Department of Medicine, Long Island Jewish Medical Center, New Hyde Park, New York 11040; ${ }^{\S}$ Department of Medicine, University of \\ California at San Diego, La Jolla, California 92037; "Department of Medicine, Institut Pasteur, 75724 Paris, France; ${ }^{\mathbb{T}}$ Department of \\ Medicine, The University of Alabama at Birmingham, Birmingham, Alabama 35294; and ** The Division of Clinical Immunology, Istituto \\ Nazionale per la Ricerca sul Cancro, Dipartmento di Oncologia Clinica e Sperimentale, Universita di Genova, 16132 Genova, Italy
}

\begin{abstract}
To better understand the stage(s) of differentiation reached by B-type chronic lymphocytic leukemia (B-CLL) cells and to gain insight into the potential role of antigenic stimulation in the development and diversification of these cells, we analyzed the rearranged $\mathrm{V}_{\mathrm{H}}$ genes expressed by $83 \mathrm{~B}-\mathrm{CLL}$ cells $\left(64 \mathrm{IgM}^{+}\right.$and 19 non-IgM $\left.{ }^{+}\right)$. Our results confirm and extend the observations of a bias in the use of certain $V_{H}, D$, and $\mathrm{J}_{\mathrm{H}}$ genes among $\mathrm{B}-\mathrm{CLL}$ cells. In addition, they indicate that the $\mathrm{V}_{\mathrm{H}}$ genes of $\sim 50 \%$ of the $\mathrm{IgM}^{+} \mathrm{B}-\mathrm{CLL}$ cells and $\sim 75 \%$ of the non-IgM ${ }^{+}$B-CLL cells can exhibit somatic mutations. The presence of mutation varies according to the $\mathrm{V}_{\mathrm{H}}$ family expressed by the B-CLL cell $\left(\mathrm{V}_{\mathrm{H}} 3\right.$ expressers displaying more mutation than $\mathrm{V}_{\mathrm{H}} 1$ and $\mathrm{V}_{\mathrm{H}} 4$ expressers). In addition, the extent of mutation can be sizeable with $\sim 32 \%$ of the $\mathrm{IgM}^{+}$cases and $\sim 68 \%$ of the non-IgM+ ${ }^{+}$cases differing by $>5 \%$ from the most similar germline gene. Approximately $20 \%$ of the mutated $V_{H}$ genes display replacement mutations in a pattern consistent with antigen selection. However, CDR3 characteristics ( $D$ and $J_{H}$ gene use and association and HCDR3 length, composition, and charge) suggest that selection for distinct $B$ cell receptors (BCR) occurs in many more B-CLL cells. Based on these data, we suggest three prototypic $B C R$, representing the $V_{H}$ genes most frequently encountered in our study. These data suggest that many B-CLL cells have been previously stimulated, placing them in the "experienced" or "memory" $\mathrm{CD5}^{+}$B cell subset. (J. Clin. Invest. 1998. 102:1515-1525.) Key words: antibodies - antigens - mutational analysis, DNA • receptors, antigen, B cell $\bullet$ hematologic neoplasms
\end{abstract}

\section{Introduction}

Over the past decade, there has been considerable interest and controversy about the immunobiology of the B cell clone that

This study was presented in part at the 7th International Workshop on Chronic Lymphocytic Leukemia, May 2-4, 1997, Crete, Greece.

Address correspondence to Nicholas Chiorazzi, North Shore University Hospital, 350 Community Drive, Manhasset, NY 11030. Phone: 516-562-1085; FAX: 516-562-1683; E-mail: nchizzi@nshs.edu

Received for publication 6 February 1998 and accepted in revised form 13 August 1998.

J. Clin. Invest.

(C) The American Society for Clinical Investigation, Inc. 0021-9738/98/10/1515/11 \$2.00

Volume 102, Number 8, October 1998, 1515-1525

http://www.jci.org is overexpanded in B-type chronic lymphocytic leukemia (B-CLL). ${ }^{1}$ In particular, two questions have been stressed: whether B-CLL cells have experienced antigenic stimulation and whether antigenic experience, if encountered, influences the development and diversification of these cells and their Ig variable region (V) genes.

Several groups, including our own, have attempted to address these questions by analyzing the expressed $\mathrm{V}$ gene repertoire of B-CLL cells. Because $\mathrm{V}$ gene repertoires are influenced by apparent combinatorial, expression, and selection biases (1-4) that occur at various stages of B cell differentiation and in distinct $\mathrm{B}$ cell subsets (5-7), it is best to compare $\mathrm{V}$ gene analyses with $B$ cells of a similar subset. In this regard, as B-CLL cells almost invariably express the CD5 antigen, it has been presumed that their $\mathrm{V}$ gene use and mutation frequency would resemble those of human $\mathrm{CD}^{+} \mathrm{B}$ cells (8) and their mouse homologues (9). Specifically, it has been assumed that B-CLL cells would accumulate little, if any, somatic mutation. This notion has been supported by several studies (10-17) and challenged by others (18-22).

In the present study, we have analyzed the $\mathrm{V}_{\mathrm{H}}$ gene sequences of a large cohort of IgM-expressing and non-IgMexpressing B-CLL cases. The results of these studies confirm that $\mathrm{V}_{\mathrm{H}}$ gene use among $\mathrm{B}-\mathrm{CLL}$ cells is not random. They also indicate that these $\mathrm{V}_{\mathrm{H}}$ genes frequently undergo somatic mutation, although mutation frequencies vary according to the $\mathrm{V}_{\mathrm{H}}$ family expressed by the B-CLL cell. Furthermore, although only a small subset of these somatically mutated $\mathrm{V}_{\mathrm{H}}$ gene sequences display replacement mutations in a pattern typical of antigen selection, other findings (e.g., complementarity-determining region[CDR]3 characteristics) suggest that selection for distinct subsets of surface membrane Ig receptors has occurred in many of these cells. These findings indicate that many B-CLL cells are derived from previously stimulated $\mathrm{CD}^{+} \mathrm{B}$ cells.

\section{Methods}

CLL samples. From a large cohort of patients with clinical and laboratory features of B-CLL, 69 patients with expansions of $\mathrm{IgM}^{+} / \mathrm{CD}^{+} /$ $\mathrm{CD} 19^{+} \mathrm{B}$ cells were chosen randomly for study. From the same cohort, 19 patients with expansions of $\mathrm{CD}^{+} / \mathrm{CD} 19^{+} \mathrm{B}$ cells expressing $\mathrm{IgG}$ or IgA were also analyzed; some of these sequences were described previously (22). PBMC from these patients, obtained from anticoagulated venous blood by density gradient centrifugation (Fi-

1. Abbreviations used in this paper: aa, amino acid; B-CLL, B-type chronic lymphocytic leukemia; CDR, complementarity-determining region; FR, framework region; $\mathrm{R}$, replacement; $\mathrm{V}$, variable. 
coll-Paque; Pharmacia LKB Biotechnology, Piscataway, NJ), were used either immediately or after thawing samples that had been cryopreserved with a programmable cell freezing machine (CryoMed, Mt. Clemens, MI).

cDNA prepared from these B-CLL samples were screened for expression of a dominant $\mathrm{V}_{\mathrm{H}}$ family (representing that of the B-CLL clone) by standard PCR and, in some cases, by ELISA-PCR. In five of the IgM-expressing cases, the ELISA-PCR revealed equal expression of two different $V_{H}$ families and, therefore, these samples were not analyzed further. These cases may represent B-CLL cells that lack allelic exclusion, as recently reported by Rassenti et al (23).

Preparation of RNA and $c D N A$ synthesis. Total RNA was isolated from PBMC using Ultraspec RNA (Biotecx Laboratories, Houston, TX) according to the manufacturer's instructions. $1 \mu \mathrm{g}$ of RNA was reverse transcribed to cDNA using $200 \mathrm{U}$ of M-MLV reverse transcriptase (GIBCO BRL, Life Technologies, Grand Island, NY), 1 U of RNase inhibitor (5 Prime 3 Prime, Boulder, CO) and 20 pmol of oligo dT primer in a total volume of $20 \mu \mathrm{l}$. Reactions were carried out at $42^{\circ} \mathrm{C}$ for $1 \mathrm{~h}$, heated at $65^{\circ} \mathrm{C}$ for $10 \mathrm{~min}$ to stop the reactions, and then diluted to a final volume of $100 \mu \mathrm{l}$.

PCR conditions for $V_{H}$ family assignment and $c D N A$ sequencing. To determine the $\mathrm{V}_{\mathrm{H}}$ gene family used by the B-CLL cells, $2 \mu \mathrm{l}$ of cDNA were amplified using a sense $\mathrm{V}_{\mathrm{H}}$ family-specific framework region (FR) primer in conjunction with the appropriate antisense $\mathrm{C}_{\mathrm{H}}$ primer (Table I). The reactions were carried out in $50 \mu$ l using 20 pmol of each primer and cycled with a 9600 GeneAmp System (Perkin Elmer Cetus, Emeryville, CA) as follows: denaturation at $94^{\circ} \mathrm{C}$ for $45 \mathrm{~s}$; annealing at $65^{\circ} \mathrm{C}$ for $45 \mathrm{~s}$; and extension at $72^{\circ} \mathrm{C}$ for $45 \mathrm{~s}$. After 35 cycles, extension was continued for an additional $10 \mathrm{~min}$. In certain instances, the $\mathrm{V}_{\mathrm{H}}$ family expressed by the B-CLL cells was confirmed by ELISA-PCR as previously described (24).

$\mathrm{V}_{\mathrm{H}}$ gene DNA sequences were determined by reamplifying $5 \mu \mathrm{l}$ of the original cDNA using the appropriate $\mathrm{V}_{\mathrm{H}}$ leader and $\mathrm{C}_{\mathrm{H}}$ primers (Table I). These reactions were carried out as follows: denaturation at $94^{\circ} \mathrm{C}$ for $45 \mathrm{~s}$; annealing at $62^{\circ} \mathrm{C}$ for $30 \mathrm{~s}$; and extension at $72^{\circ} \mathrm{C}$ for $45 \mathrm{~s}$. After $30-32$ cycles, extension was continued for an additional 10 min. PCR products were sequenced directly after purification with Wizard PCR Preps (Promega, Madison, WI) using an automated sequenator (Applied Biosystems, Foster City, CA). In some instances

Table I. Oligonucleotide Primers Used for $V_{H}$ Gene Amplification

$\begin{array}{ll}\mathrm{V}_{\mathrm{H}} \text { Leader primers } & \\ \mathrm{V}_{\mathrm{H}} 1 \text { and } \mathrm{V}_{\mathrm{H}} 7: & \text { ATGGACTGGACCTGGAGG } \\ \mathrm{V}_{\mathrm{H}} 2: & \text { CAC(GA)CTCCTGCTGCTGACCA } \\ \mathrm{V}_{\mathrm{H}} 3 \mathrm{a}: & \text { GCTGGGTTTCCTTTTGC } \\ \mathrm{V}_{\mathrm{H}} 3 \mathrm{~b}: & \text { ATGGAGTT(TG)GG(AG)CTGAGCTG } \\ \mathrm{V}_{\mathrm{H}} 4: & \text { GCTCCCAGATGGGGTCCTG } \\ \mathrm{V}_{\mathrm{H}} 5: & \text { CTCCTCCTGGCTGTTCTCC } \\ \mathrm{V}_{\mathrm{H}} 6: & \text { CTGTCTCCTTCCTCATCTTCC } \\ \mathrm{V}_{\mathrm{H}} \text { Family-specific FR1 primers } \\ \mathrm{V}_{\mathrm{H}} 1: & \text { GT(GA)CAGTCTGG(GA)(GC)CTGAGG } \\ \mathrm{V}_{\mathrm{H}} 2: & \text { AAACCCACA(CG)AGACCCTCAC } \\ \mathrm{V}_{\mathrm{H}} 3: & \text { GGTCCCT(GT)AGACTCTCCTGT } \\ \mathrm{V}_{\mathrm{H}} 4: & \text { (CG)ACCCTGTCCCTCACCTGC } \\ \mathrm{V}_{\mathrm{H}} 5: & \text { CAAGCCCGGGGAGTCTCTG } \\ \mathrm{V}_{\mathrm{H}} 6: & \text { GGTGCAATCTGGGTCTGAGTT } \\ \mathrm{V}_{\mathrm{H}} 7: & \text { CAGGAGAAAGTGATGGAGTCG } \\ \mathrm{C}_{\mathrm{H}} \text { Isotype-specific primers } \\ \text { IgM: } & \text { GGGGAAGTAGTCCTTGACCAG } \\ \text { IgG: } & \text { GAGGCTCAGCGGGAAGACCTT } \\ \text { IgA: } & \end{array}$

where mutations were detected, an independent PCR product was generated. This product was then either sequenced directly or cloned into TA vector (Invitrogen, San Diego, CA), processed using Wizard minipreps (Promega), and sequenced using M13 forward and reverse primers.

Analyses of $V_{H}, D$, and $J_{H}$ sequences. Sequences were compared with those in the V BASE sequence directory (25) using MacVector software, version 6.0 (Eastern Kodak Co., New Haven, CT). In those instances where a $>1 \%$ deviation from a germline sequence was found in an expressed $\mathrm{V}_{\mathrm{H}}$ gene, the algorithm of Chang and Casali (26) was used to determine whether "antigen selection" of the replacement (R) mutations had occurred, taking into account the inherent susceptibility of CDR to R mutations. Thus, the expected number of $\mathrm{R}$ mutations in CDR and FR was calculated using the formula $\mathrm{R}=$ $n \times C D R R f($ or FR Rf) $\times$ CDRrel (or FRrel). Where $n$ is the total number of observed mutations, $R f$ is the replacement frequency inherent to the CDR or FR, and CDRrel and FRrel are the relative sizes of the segments. A binomial probability model was used to evaluate whether the excess of R mutations in CDR or the scarcity in FR was due to chance (26).

The criteria of Corbett et al. (i.e., the requirement for 10 consecutive nucleotides of identity [27]) were used to assign members of the longer D gene families (D2 and D3); for members of the shorter D families (D1, D3, D4, D5, D6, D7), a requirement for seven consecutive nucleotides and no more than two differences was used. The DIR segments and the "minor" D segments were eliminated from these analyses as suggested (27). Reading frames of the D segments were categorized as yielding either a stop codon, a hydrophilic segment, or a hydrophobic segment $(27,28)$.

Analyses of HCDR3 rearrangements. HCDR3 length was determined by counting the number of amino acids (aa) between position 94 at the end of FR3 (usually two aa downstream of the conserved cystine) and position 102 at the beginning of FR4 (a conserved tryptophan in all $\mathrm{J}_{\mathrm{H}}$ segments). Acidic and basic aa and HCDR3 charge, as defined by an estimated pI, were determined using the MacVector software programs.

\section{Results}

$V_{H}$ gene use. The characteristics of the $\mathrm{IgH}$ chain variable region gene cDNA sequences of the $64 \mathrm{IgM}^{+} \mathrm{B}-\mathrm{CLL}$ cells and the 19 non- $\operatorname{IgM}^{+}\left(17 \mathrm{IgG}^{+}\right.$and $\left.2 \mathrm{IgA}^{+}\right)$B-CLL cells are listed in Tables II and III. These data indicate that the $\mathrm{V}_{\mathrm{H}}$ genes used by these 81 leukemias were derived from each of the seven human $\mathrm{V}_{\mathrm{H}}$ gene families in the following distribution: $\mathrm{V}_{\mathrm{H}} 1$ : $24.1 \%, \mathrm{~V}_{\mathrm{H}} 2: 1.2 \%, \mathrm{~V}_{\mathrm{H}} 3: 38.6 \%, \mathrm{~V}_{\mathrm{H}} 4: 30.1 \%, \mathrm{~V}_{\mathrm{H}} 5: 2.4 \%, \mathrm{~V}_{\mathrm{H}} 6$ : $2.4 \%$, and $\mathrm{V}_{\mathrm{H}} 7: 1.2 \%$. When divided into $\operatorname{IgM}^{+}$and non- $\operatorname{IgM}^{+}$ categories, the $\mathrm{V}_{\mathrm{H}}$ family distributions were different. For the $\operatorname{IgM}^{+}$samples, the percentages of the major families were $\mathrm{V}_{\mathrm{H}} 1$ : $28.1 \%, \mathrm{~V}_{\mathrm{H}} 3: 37.5 \%$, and $\mathrm{V}_{\mathrm{H}} 4: 26.6 \%$, whereas for the non$\operatorname{IgM}^{+}$cases, they were $\mathrm{V}_{\mathrm{H}} 1: 10.5 \%, \mathrm{~V}_{\mathrm{H}} 3: 42.1 \%$, and $\mathrm{V}_{\mathrm{H}} 4$ : $42.1 \%$.

Overall, the most frequently encountered gene was $\mathrm{V}_{\mathrm{H}} 4-34$ ( $n=15)$, which represented $18.1 \%$ of all the genes detected and $60 \%$ of the $\mathrm{V}_{\mathrm{H}} 4$ genes (Tables II and III). The distribution of 4-34 among the $\mathrm{V}_{\mathrm{H}^{4}}$ genes of the $\mathrm{IgM}^{+}$group was $52.9 \%$ and of the non- $\operatorname{IgM}^{+}$group, $75 \%$. The next two most frequently found genes were $\mathrm{V}_{\mathrm{H}} 3-07(n=10)$ and $\mathrm{V}_{\mathrm{H}} 1-69(n=6)$, which comprised 12.1 and $7.2 \%$ of the total and 31.3 and $30.0 \%$ of their respective families. These two genes were found almost exclusively in the IgM-expressing group. Several other genes were found in multiple cases: 1-02 $(n=5), 1-18$ $(n=4), 1-03(n=3), 3-23(n=4), 3-30(n=3), 4-39(n=4)$, and 4-59 $(n=3)$. Each of these was represented in both the $\operatorname{IgM}^{+}$and the non- $\operatorname{IgM}{ }^{+}$groups, except for 4-59 which was 


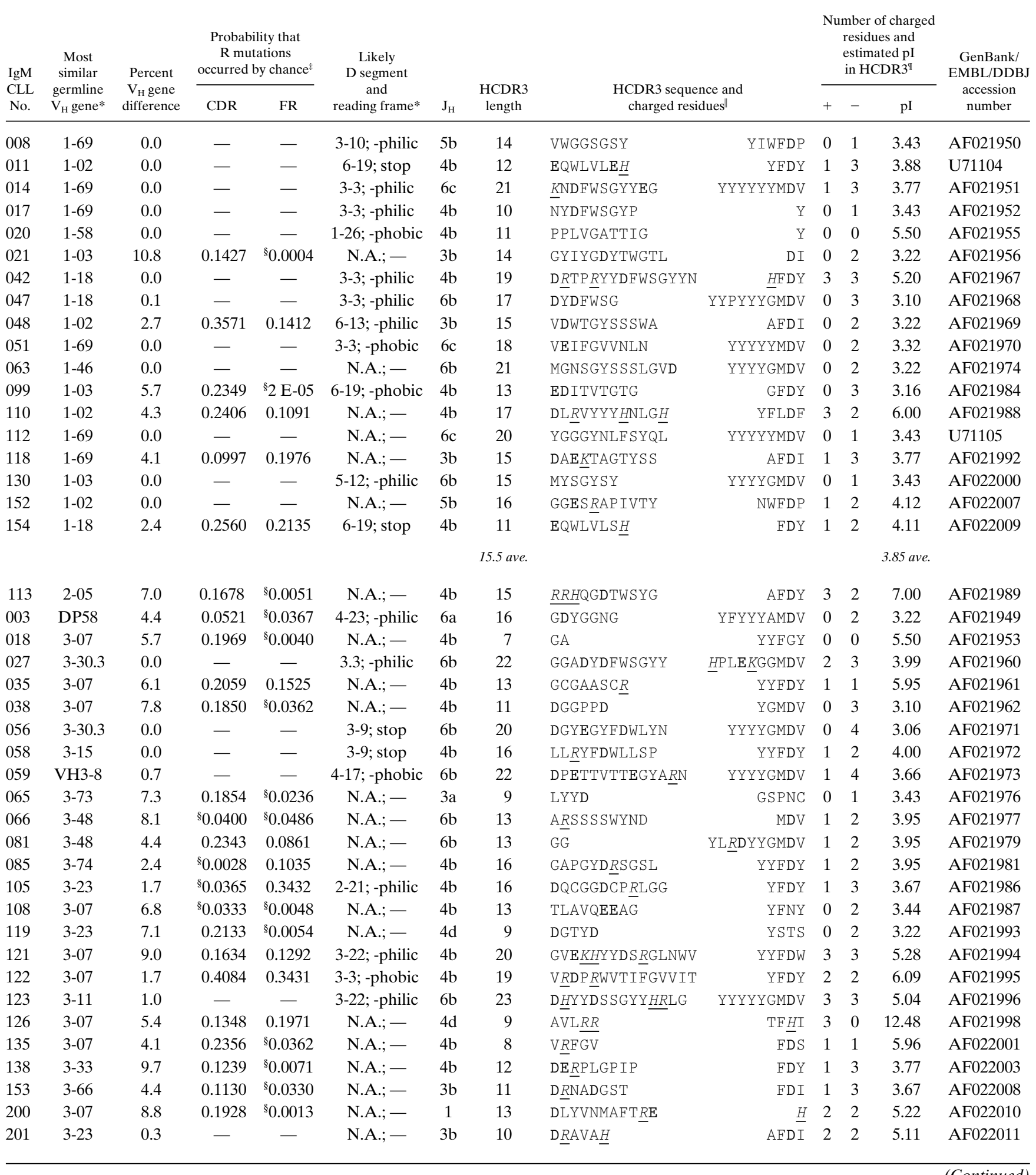

(Continued)

present only in the $\operatorname{IgM}^{+}$group and 3-30 which was found only in the non- $\operatorname{IgM}^{+}$group.

$V_{H}$ gene mutations. A significant level of somatic mutation was found in both the $\operatorname{IgM}^{+}$and the non- $\operatorname{IgM}^{+}$groups (Tables II and III). Approximately half $(51.6 \% ; 33 / 64)$ of the IgM-expressing B-CLL cells differed by $2.0 \%$ or more from the most similar germline counterpart and 32.8\% (21/64) differed by $>5.0 \%$. Among the isotype class switched B-CLL cells, even more extensive mutation was detected with $73.7 \%$ (14/19) differing by $2.0 \%$ or more and $68.4 \%$ (13/19) differing by $>5.0 \%$.

Mutations detected in the leukemic cells varied according 


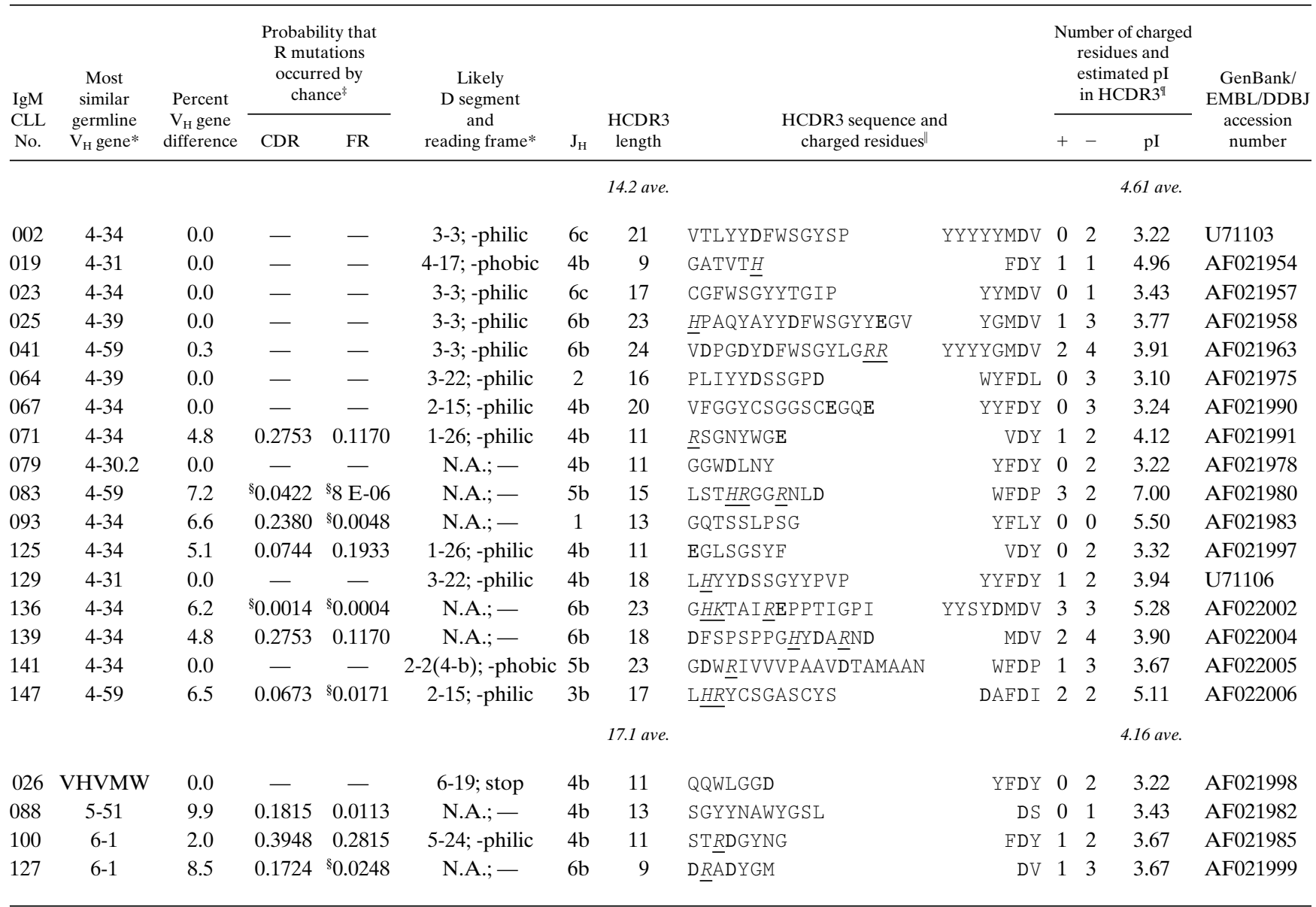

*Genes identified by two-number code with first number indicating the family, and, the second, the relative position in the locus from $\mathrm{V}_{\mathrm{H}}$ to $\mathrm{J}_{\mathrm{H}}(27$, 29). N.A.: not assignable. ${ }^{\ddagger}$ Calculated according to Chang and Casali using a binomial probability model to evaluate whether the excess of $R$ mutations in CDR or the scarcity in FR was due to chance (26). ${ }^{8}$ Denotes statistically significant difference $(P<0.05)$. "Amino acids on left contributed by D segment; those on right by $\mathrm{J}_{\mathrm{H}}$. Positively charged aa are italicized and underlined; negatively charged residues are represented in bold type. ${ }^{\mathrm{I}} \mathrm{Calcu}-$ lated from the deduced aa sequence using MacVector software, version 6.0.

to $\mathrm{V}_{\mathrm{H}}$ family and specific $\mathrm{V}_{\mathrm{H}}$ gene use (Tables II and III). These differences were most obvious among the $\operatorname{IgM}^{+}$samples. Thus, $66.7 \%$ of the $\mathrm{V}_{\mathrm{H}} 3$ genes displayed $2.0 \%$ or more mutations, whereas only $33.3 \%$ of the $\mathrm{V}_{\mathrm{H}} 1$ genes differed by $>2 \%(P<0.005$; Mann Whitney Test $)$. Furthermore, $45.8 \%$ of the $\mathrm{V}_{\mathrm{H}} 3$ genes displayed $>5 \%$ difference in contrast to only $11.1 \%$ of the $\mathrm{V}_{\mathrm{H}} 1$ genes. This difference was more striking when the two most frequently encountered genes in these two families (3-07 and 1-69) were compared. Thus, $88.9 \%$ of the 3-07 genes differed by $2 \%$, whereas only $16.7 \%$ of the $1-69$ genes had this level of difference $(P<0.005$; Mann Whitney test). Similarly, $77.8 \%$ of the 3-07 genes differed by $>5 \%$, whereas none of the 1-69 genes had $>5 \%$ mutations. $41 \%$ of the $\mathrm{V}_{\mathrm{H}} 4$ genes of the $\mathrm{IgM}^{+}$group displayed $2 \%$ or more mutation, and the most frequently encountered gene, 4-34, was mutated in $55.6 \%$ of the cases.

Differences in the level of mutations among the various $V_{H}$ families were also seen in the non- $\operatorname{IgM}^{+}$group, although it was less obvious due to the lower number of cases studied. Thus, $87.5 \%(7 / 8)$ of the $\mathrm{V}_{\mathrm{H}} 3$ - and $75 \%(6 / 8)$ of the $\mathrm{V}_{\mathrm{H}} 4$-expressing cases exhibited $2 \%$ or greater difference from their germline counterparts (Tables II and III). Indeed, in every case but one
(CLL No. 183), these B cells displayed $\geq 5 \%$ difference. Furthermore, in $100 \%$ of the non- $\mathrm{IgM}^{+}$cases, the 4-34 gene was mutated. Remarkably, the $\mathrm{V}_{\mathrm{H}}$ 4-39-expressing cases exhibited virtually no mutations in both the $\operatorname{IgM}^{+}$and the non- $\operatorname{IgM}^{+}$settings.

$D$ segment use and reading frame. We were able to identify D genes in $50.6 \%(42 / 83)$ of the B-CLL cases examined (Tables II and III). Gene assignments were made more readily for the IgM-expressing B-CLL cells than for the isotypeswitched, non-IgM+ ${ }^{+}$cases; indeed, in only seven of the latter cases was D segment identification possible.

Among the $35 \mathrm{IgM}^{+}$cases with identifiable D segments, genes of the D3 family were found most frequently $(47.6 \%)$, followed by D6 (16.7\%) and D2 (14.3\%) family genes. Among the non-IgM ${ }^{+}$cases, genes of these three D families were used in similar proportions. D3 gene use was most frequent among the $\mathrm{V}_{\mathrm{H}} 3$-expressing cells $(66.7 \%)$ and was similar among the $\mathrm{V}_{\mathrm{H}} 1$ - and $\mathrm{V}_{\mathrm{H}} 4$-expressing cases $(46.2 \%$ and $41.2 \%$, respectively). The most frequently used D3 segment was D3-3 (previously called DXP4), which was found in $26.2 \%$ of the identifiable D genes (11/42 cases) and in $50 \%$ of those cases expressing the $V_{H} 1-69$ gene. In general, $D$ segments were ex- 


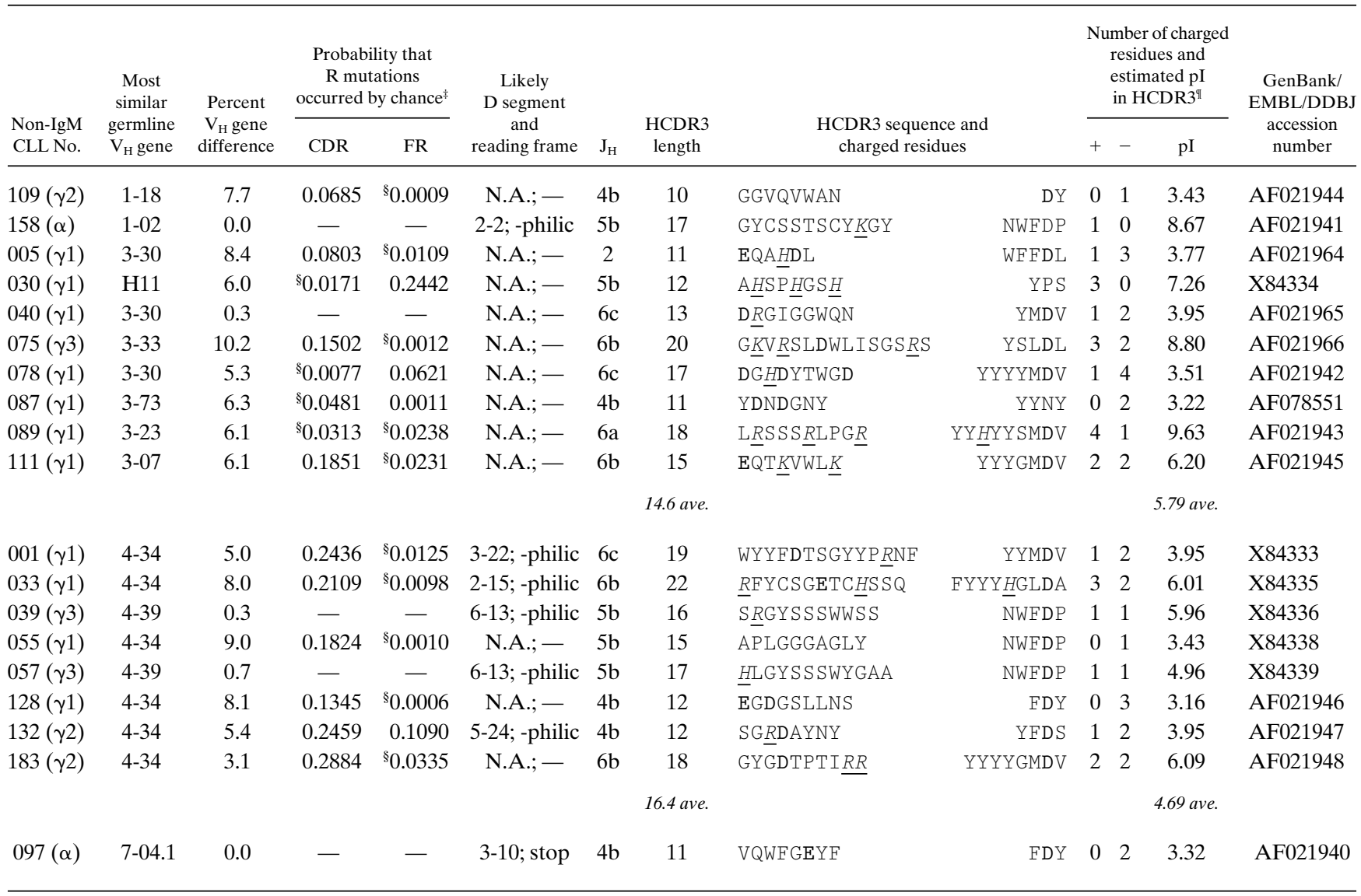

See legend to Table II.

pressed in their hydrophilic reading frames $(71.4 \% ; 30 / 42$ cases; Tables II and III).

$J_{H}$ gene use. $\mathrm{J}_{\mathrm{H}}$ use differed between the $\operatorname{IgM}^{+}$and the non-IgM ${ }^{+}$B-CLL cases (Tables II and III). Among the $\operatorname{IgM}^{+}$ group, $\mathrm{J}_{\mathrm{H}} 4, \mathrm{~J}_{\mathrm{H}} 6$, and $\mathrm{J}_{\mathrm{H}} 3$ genes predominated with an overall distribution as follows: $\mathrm{J}_{\mathrm{H}} 1: 3.1 \%, \mathrm{~J}_{\mathrm{H}} 2: 1.6 \%, \mathrm{~J}_{\mathrm{H}} 3: 10.8 \%, \mathrm{~J}_{\mathrm{H}} 4$ : $46.9 \%, \mathrm{~J}_{\mathrm{H}} 5: 6.3 \%$, and $\mathrm{J}_{\mathrm{H}} 6: 31.3 \%$. In contrast, among the non$\mathrm{IgM}^{+}$group, $\mathrm{J}_{\mathrm{H}} 4$ and $\mathrm{J}_{\mathrm{H}} 3$ use was less $(26.3$ and $0 \%$, respectively), with an increase in $\mathrm{J}_{\mathrm{H}} 5(26.3 \%)$ and $\mathrm{J}_{\mathrm{H}} 6(42.1 \%)$ use.

The pattern of $\mathrm{J}_{\mathrm{H}}$ use differed among the various $\mathrm{V}_{\mathrm{H}}$ families and among the most frequently encountered members of the $\mathrm{V}_{\mathrm{H}} 1,3$, and 4 families. Thus, $88.9 \%$ of the $3-07$ genes used a $\mathrm{J}_{\mathrm{H}} 4$ gene segment compared to $16.7 \%$ of those expressing a $1-69$ gene $(P<0.05$; Fisher Exact test $)$. Furthermore, $50 \%$ of the 1-69 genes used a $\mathrm{J}_{\mathrm{H}} 6$ segment compared to none for 3-07 $(P<0.05)$. Finally, $33.3 \%$ of the $4-34$ genes used a $\mathrm{J}_{\mathrm{H}} 4$ segment and $46.7 \%$ used a $\mathrm{J}_{\mathrm{H}} 6$ segment.

CDR3 length. The average HCDR3 length for all samples was 15.12 aa (Tables II and III). This value did not differ significantly between the $\operatorname{IgM}^{+}$(15.14) and non-IgM+ (15.05) samples. When CDR3 length was analyzed in relation to the $\mathrm{V}_{\mathrm{H}}$ family incorporated into the rearranged gene, some differences were seen $\left(\mathrm{V}_{\mathrm{H}} 4: 16.84 ; \mathrm{V}_{\mathrm{H}} 1: 15.3 ; \mathrm{V}_{\mathrm{H}} 3: 14.31\right)$. However, when CDR3 length was compared among the most frequently used genes in these families, these differences were more striking. Thus, the 3-07 gene had an average length of 12.80, considerably shorter than the composite average of 15.11 aa. In con- trast, the average length among the 4-34-expressing B-CLL cells was longer (17.0 aa). Furthermore, these 4-34-expressing cells could be divided into two categories: those with CDR3 lengths longer than the average $(20.11 ; n=9)$ that usually contained a $\mathrm{J}_{\mathrm{H}} 6$ or $\mathrm{J}_{\mathrm{H}} 5$ segment, and those shorter than the average $(12.33 ; n=6)$ that usually contained a $\mathrm{J}_{\mathrm{H}} 4$ segment. Finally, the CDR3 lengths among the 1-69-expressing B-CLL cells were longer than the average (16.33 versus 15.11$)$.

CDR3 composition and charge. The HCDR3 of the $\mathrm{IgM}^{+}$ group frequently contained relatively long stretches of tyrosines at their $3^{\prime}$ ends coded for by the $\mathrm{J}_{\mathrm{H}} 6$ segment (Table II). Among the $\mathrm{B}$ cells expressing $\mathrm{V}_{\mathrm{H}} 1$ genes, these germline residues were altered only negligibly by somatic events. In contrast, these $\mathrm{J}_{\mathrm{H}} 6$ sequences were altered appreciably in three of seven B-CLL cells using $\mathrm{V}_{\mathrm{H}} 3$ genes (Nos. 027, 066, and 081), and three of six using $\mathrm{V}_{\mathrm{H}^{4}}$ genes (Nos. 023, 025, and 139). This was also reflected in two of the five non- $\operatorname{IgM}^{+} \mathrm{B}-\mathrm{CLL}$ cells using $\mathrm{V}_{\mathrm{H}} 3$ genes (Nos. 040 and 075) and all of those using $\mathrm{V}_{\mathrm{H}^{4}} 4$ genes (Table III).

In the absence of charged residues, rearranged HCDR3 usually have estimated pI values of 5.50 (e.g., CLL Nos. 020, 018, and 093; Table II). However, due to the presence of D and $\mathrm{J}_{\mathrm{H}}$ segments that code for negatively charged residues (e.g., aspartic acid: D), most of the $\mathrm{IgM}^{+}$B-CLL HCDR3 segments were more acidic with estimated pI values as low as 3.06 (e.g., CLL Nos. 047, 038, 056, and 064; Table II). In only rare instances did positively charged residues offset this bias and re- 
sult in pI > $5.50\left(6 / 63\right.$ for $\operatorname{IgM}^{+}$; CLL Nos. $110,113,122,126$, 083, and 135). The $\operatorname{IgM}^{+}$B-CLL cells using $\mathrm{V}_{\mathrm{H}} 1$ genes had the least of these residues and, therefore, as a group had the lowest average estimated $\mathrm{pI}$ (3.85). In contrast, those B-CLL cells using $\mathrm{V}_{\mathrm{H}} 3$ genes had more of these positively charged residues and had an average estimated $\mathrm{pI}$ of 4.61. The $\mathrm{V}_{\mathrm{H}}$ 4-expressing B-CLL cells had an intermediate phenotype with an average estimated $\mathrm{pI}$ of 4.16. In concert with this principle, the $\mathrm{V}_{\mathrm{H}}$ 1-69-expressing B-CLL cells had an average pI of 3.53; those expressing 4-34 an average pI of 4.37; and those using 3-07 a pI of 5.89 .

Among the non-IgM ${ }^{+}$group, HCDR3 charge was more heterogeneous (Table III). In $42.1 \%$ of cases, the estimated pI exceeded 5.50. Indeed, in 14/19 instances (73.7\%), at least one positively charged residue was present in the CDR3 segment and, in those cases where the pI exceeded 5.50, there was an average of 2.4 positively charged residues/CDR3. Similar to the $\mathrm{IgM}^{+}$B-CLL cells, the non-IgM+ $\mathrm{I}^{+}$cells that expressed $\mathrm{V}_{\mathrm{H}} 3$ genes had the highest estimated pI (5.79).

\section{Discussion}

The non-random use of gene segments, the presence and extent of mutation, and the apparent constraints in HCDR3 structure observed in these cases provide further insights into the stage of maturation and the potential role of antigen stimulation in the evolution of these leukemic cells.

Gene use. To improve the power of these comparisons, we combined our findings for $\mathrm{IgM}^{+}$B-CLL cells with those from other B-CLL studies (21,30-38) and then compared these data with those for normal adult $\mathrm{CD}^{+}$blood B cells (39). With this approach, it became apparent that $\mathrm{V}_{\mathrm{H}}$ gene family use was not comparable to that in the normal repertoire; rather, there was a statistically significant increase in $\mathrm{V}_{\mathrm{H}} 1$ gene expression and a statistically significant decrease in $\mathrm{V}_{\mathrm{H}} 3$ expression in B-CLL (Fig. 1). $\mathrm{J}_{\mathrm{H}}$ family use among the pooled $\mathrm{IgM}^{+}$B-CLL cells was not different from that of the normal $\mathrm{CD}^{+} \mathrm{B}$ cell repertoire (data not shown).

$\mathrm{V}_{\mathrm{H}}$ 4-34, 3-07, and 1-69 were the most commonly expressed $\mathrm{V}_{\mathrm{H}}$ genes in our B-CLL patients. Although neither 4-34 nor 3-07 were identified as dominant genes in several previous surveys of CLL patients (17, 40; reviewed in reference 41$)$, the 4-34 gene has been found in virtually all cases of cold aggluti- nin disease (42-44), frequently in diffuse large cell lymphoma (45) and autoimmune disorders (46), and virtually never in multiple myeloma $(40,47)$. Interestingly, when we combine our B-CLL cases with those in the literature $(21,30-38)$, the frequency of $\mathrm{V}_{\mathrm{H}}$ 4-34 and 3-07 expression matches that in the normal adult $\mathrm{CD}^{+}$repertoire, although there is a statistically significant overrepresentation of the $\mathrm{V}_{\mathrm{H}}$ 1-69 gene (Fig. 2). This latter finding confirms studies of Kipps, Carson, and coworkers, who have indicated the prominence of the 1-69 gene (31) and some of its alleles (48) in B-CLL. Although several other $\mathrm{V}_{\mathrm{H}} 1$ and $\mathrm{V}_{\mathrm{H}} 3$ genes (e.g., 1-02, 1-18, and 3-23) were found often in the combined B-CLL repertoire, their expression did not differ significantly from the normal. Significant underrepresentations were found for the $V_{H} 3-30, V_{H} 3-30.3$, and $V_{H}$ 3-33 genes (Fig. 2), which may be responsible for the decreased use of $\mathrm{V}_{\mathrm{H}} 3$ genes illustrated in Fig. 1.

However, all of these comparisons need to be evaluated with caution because of the limited numbers of normal $\mathrm{CD}^{+}$ and $\mathrm{CD}^{-}$blood $\mathrm{B}$ cell sequences that are presently available in the literature for comparison. Indeed, because of this relative dearth of data, we have used the $\mathrm{V}_{\mathrm{H}}$ sequences of 144 individual $\mathrm{CD}^{+}$blood B cells from two normal adults (39). In addition, genetic differences in gene copy numbers may be important factors in determining gene expression. This may be especially relevant as it has been reported that copies of the $\mathrm{V}_{\mathrm{H}}$ 1-69 and 3-23 genes, which are frequently found in B-CLL cells, and the $\mathrm{V}_{\mathrm{H}}$ 3-30 genes, which we have found underrepresented in this study, vary among individuals (49-51).

$\mathrm{J}_{\mathrm{H}}$ segment use differed among the three most frequently encountered genes in that $\sim 90 \%$ of the $\mathrm{V}_{\mathrm{H}} 3-07$ genes were associated with a $J_{H} 4$ segment, whereas $\sim 50 \%$ of the $V_{H} 1-69$ and $\mathrm{V}_{\mathrm{H}}$ 4-34 genes were associated with a $\mathrm{J}_{\mathrm{H}} 6$ segment. D3 family genes were found most frequently in B-CLL cells (47.6\%), followed by D6 (16.7\%) and D2 (14.3\%) family genes. These percentages are very similar to those recently identified in 451 rearranged HCDR3 from antibodies in the databases (27). The individual D segment used most frequently in our cohort of B-CLL cells was D3-3 which was present in $\sim 26 \%$ of the identifiable $\mathrm{D}$ segments, a frequency that is almost threefold more than that found in the 451 normal sequences mentioned above (26.2 versus $9.6 \%)$. It has been reported (48) that $\mathrm{V}_{\mathrm{H}} 1-69^{+} \mathrm{B}$-CLL cells frequently use the D3-3 (DXP4) segment. In our cases, $50 \%$ of the $1-69$ genes
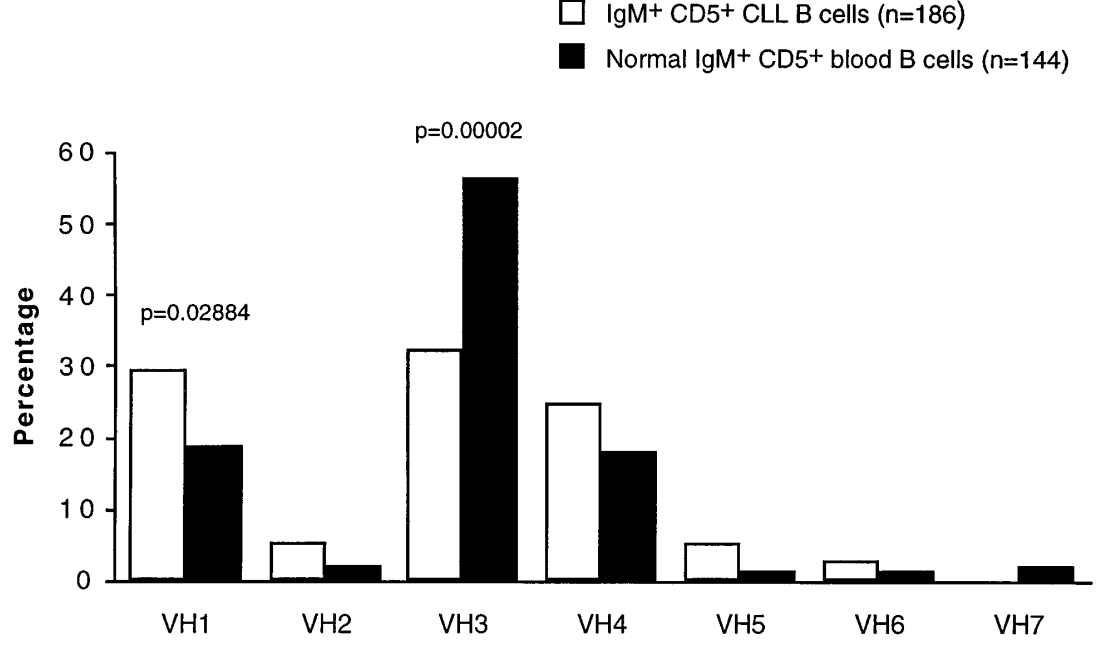

Figure 1. Comparison of $\mathrm{V}_{\mathrm{H}}$ gene use between $\mathrm{IgM}^{+} \mathrm{B}-\mathrm{CLL}$ cases and normal blood B cells. The $\mathrm{IgM}^{+} \mathrm{B}-\mathrm{CLL}$ cases represent a pool of those reported in this study and those compiled by Schroeder and Dighiero (21), and available in other studies (30-38) and/or in GenBank/EMBL/ DDBJ. Normal IgM ${ }^{+} \mathrm{CD}^{+}$blood B cell sequences were derived from single $\mathrm{B}$ cells of two healthy adult males as reported by Brezinschek et al (39). Statistical comparisons were performed using the Fisher's Exact test. 


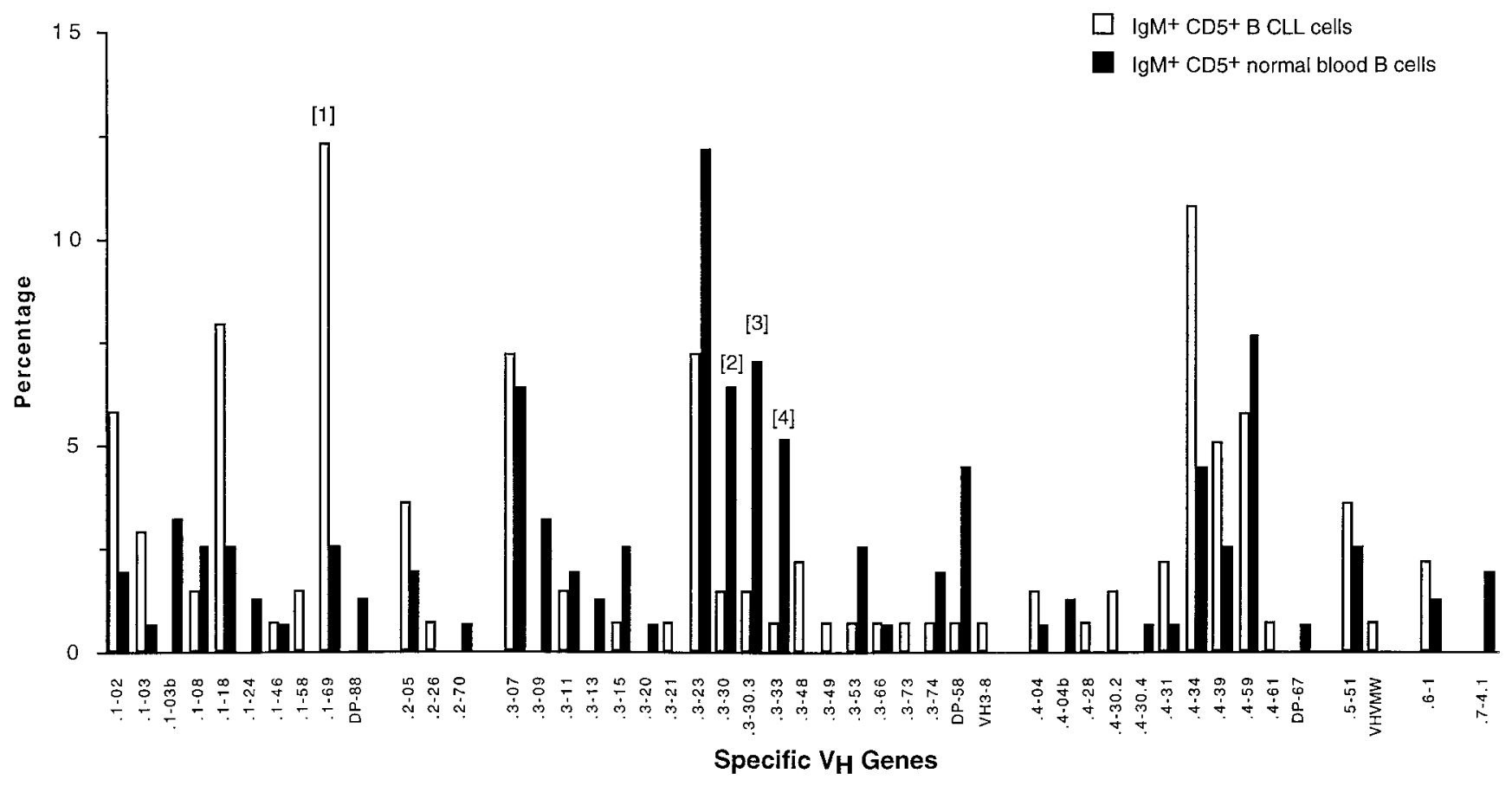

Figure 2. Comparison of specific $\mathrm{V}_{\mathrm{H}}$ gene use between $\operatorname{IgM}^{+}$B-CLL cases and normal blood B cells. Statistical comparisons were performed using the Fisher's Exact test: (1) $P=0.0011$; (2) $P=0.0394$; (3) $P=0.0230$; and (4) $P=0.0397$.

were linked with this D gene. Finally, D segment expression was markedly biased in favor of hydrophilic reading frames, especially in the non-IgM ${ }^{+}$group. This finding is consistent with the normal adult B cell repertoire $(27,28)$.

Somatic mutation. Approximately $57 \%$ of the B-CLL $\mathrm{V}_{\mathrm{H}}$ gene sequences determined in this study were mutated. Indeed, we found mutations $\geq 2 \%$ in $50.8 \%$ of the $\operatorname{IgM}^{+}$B-CLL cells and mutations $>5 \%$ in $31.8 \%$ of these patients. An even higher percentage of the isotype-switched B-CLL cells exhibited these levels of mutation (72.2 and $66.7 \%$, respectively).
Although the percentage of $\operatorname{IgM}^{+}$B-CLL cells expressing mutations in the $2-5 \%$ range was similar to that reported for normal $\mathrm{CD}^{+}$blood B cells (18.1 versus $19.1 \%$; [39]), the percentage of B-CLL cells expressing mutations in the $>5 \%$ range was significantly different $(P<0.000001)$ from these normal $\mathrm{CD}^{+} \mathrm{B}$ cells. Indeed, there were ten times as many cases of $\mathrm{IgM}^{+} \mathrm{CD}^{+} \mathrm{B}-\mathrm{CLL}$ with mutations $>5 \%$ than in the normal (31.8 versus $3.5 \%$ ). Surprisingly, this frequency even exceeded that reported for circulating $\mathrm{CD}^{-} \mathrm{B}$ cells (31.8 versus $17.6 \%$ ). These latter comparisons are presented graphically in Fig. 3.

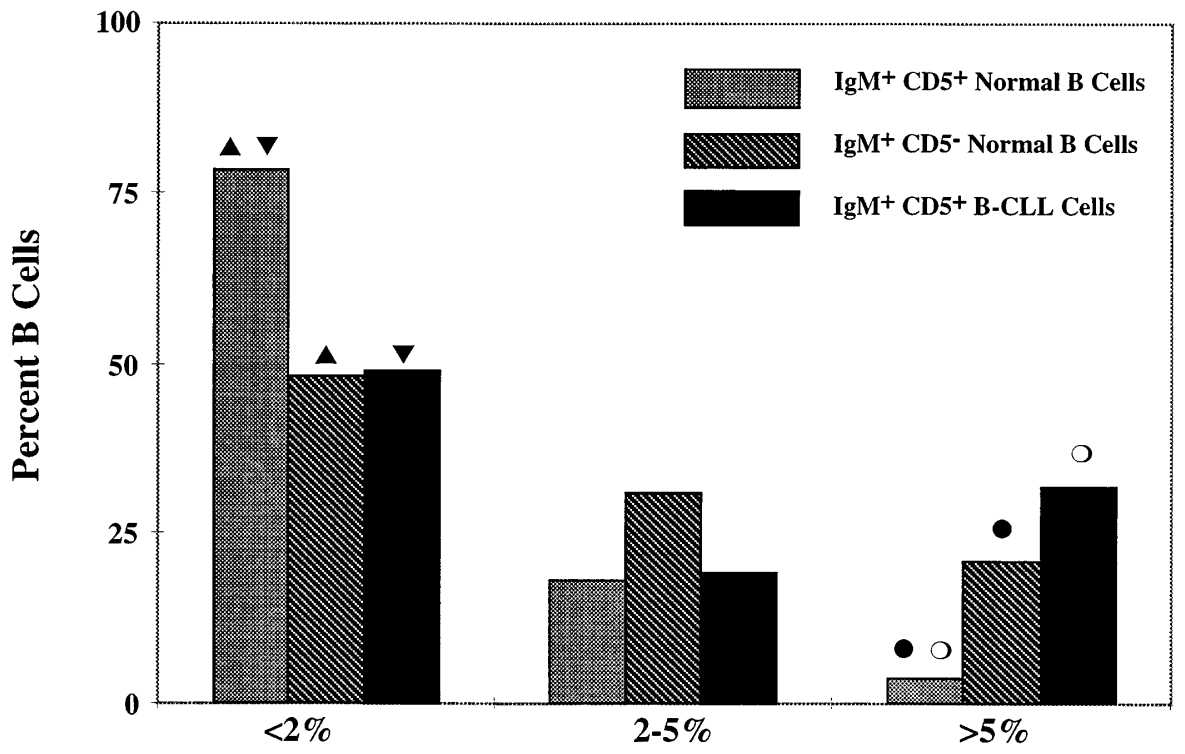

Percent Difference from Progenitor Germline Gene
Figure 3. Comparison of extent of $\mathrm{V}_{\mathrm{H}}$ gene mutation between normal peripheral blood $\mathrm{IgM}^{+} \mathrm{CD}^{+}$and $\mathrm{IgM}^{+} \mathrm{CD}^{-} \mathrm{B}$ cells, and the $\mathrm{IgM}^{+} \mathrm{CD}^{+} \mathrm{B}-\mathrm{CLL}$ cells in this study. The $\mathrm{IgM}^{+} \mathrm{CD}^{+}$blood B cells $(n=144)$ and the $\operatorname{IgM}^{+} \mathrm{CD}^{-} \mathrm{B}$ cells $(n=206)$ are from reference 39 ; the $\mathrm{IgM}^{+} \mathrm{CD}^{+} \mathrm{B}-\mathrm{CLL}$ cells $(n=63)$ are from this study. Statistically significant differences (Fisher's Exact test) were found in the $<2 \%$ group between the $\mathrm{CD}^{+}$and the $\mathrm{CD}^{-}$normal B cells (regular triangle) and between the $\mathrm{CD}^{+}$normal cells and the B-CLL cells (inverted triangle) with $P$ values for both $<0.00005$. Similarly, within the $>5 \%$ group, statistically significant differences were found in the same two comparisons (closed and open circles, respectively) with $P$ values for both $<0.000001$. 
However, these mutations did not occur uniformly among the various $V_{H}$ gene families. Indeed, there was a $V_{H}$ familyrelated hierarchy of mutation $\left(\mathrm{V}_{\mathrm{H}} 3>\mathrm{V}_{\mathrm{H}} 4>\mathrm{V}_{\mathrm{H}} 1\right)$. This was most obvious when comparing the 3-07 (90\% of cases mutated), 4-34 (73.3\%), and 1-69 (16.7\%) genes. The observation that 1-69-expressing B-CLL cells have a lower frequency of mutation is supported by the study of Johnson et al. (48) that found that only 1 of $26 \mathrm{~V}_{\mathrm{H}} 1-69^{+}$B-CLL cells had $<99 \%$ similarity to a $V_{H} 1-69$ allele. This $V_{H}$ family-related difference in mutation may explain, in part, the discrepancies about $\mathrm{V}_{\mathrm{H}}$ gene mutation reported in other B-CLL studies, as cohorts with disproportionate numbers of either $\mathrm{V}_{\mathrm{H}} 1$ - or $\mathrm{V}_{\mathrm{H}} 3$-expressing cases would likely yield conflicting results. A further confounding issue may be the fact that certain B-CLL cells can productively express two $\mathrm{V}_{\mathrm{H}}$ genes, which can differ in the presence and extent of mutation (23).

$\mathrm{B}$ cells with receptors that have been selected by antigen often display a higher frequency of $\mathrm{R}$ mutations in the CDR than in the FR $(52,53)$. However, when assessing the possibility of antigen selection, the inherent susceptibility of the progenitor germline gene to aa replacement needs to be considered. Based on the algorithm of Chang and Casali that incorporates these considerations (26), $20 \%$ of our B-CLL cells demonstrate antigen selection of R mutations (noted by $\S$ in Tables II and III).

However, it is important to recognize that such algorithms are statistical approaches that are unable to account for all aspects of "selection biology" and, therefore, may not always accurately reflect the influences of antigen. For example, in some instances, high affinity antigen binding may depend on only one or a few critical amino acids (54-56). In these instances, the occurrence of an "advantageous" mutation would permit survival and positive selection of the mutating B cells. If, however, some of these positively selected, mutated B cells subsequently accumulate additional mutations outside of the CDR that do not alter selection by antigen, these "neutral" mutations might then result in an algorithmic determination that suggests statistical insignificance, albeit in the setting of definite biological significance. Furthermore, recent studies suggest that R mutations located outside of the CDR can enhance antigen binding (57), a fact that these algorithms by design cannot consider. Conversely, antigen selection could favor the preservation of certain residues. For example, certain portions of the FR are important for superantigen binding $(58,59)$ and these need to be preserved to permit superantigen-mediated selection and rescue. Indeed, in this study, 61.7\% (29/47) of the cases exhibited statistically significant preservations of FR sequences (Tables II and III, marked with $\S$ ). Preservation of FR integrity is consistent with the necessity for B cells to maintain an intact B cell receptor (60). Finally, these algorithms cannot take into account the structure of the $\mathrm{H}$ and L CDR3, the regions which have the most intimate contact with antigen.

CDR3 characteristics. We were able to define three HCDR3 categories among our B-CLL cases based on differences in length, aa composition, and charge. Each of these varied in a $V_{H}$ family-related manner. First, the CDR3 length of $\mathrm{V}_{\mathrm{H}} 4$-expressing B-CLL cells was greater than in $\mathrm{V}_{\mathrm{H}} 1$-expressing $\mathrm{B}$ cells and this was in turn greater than in $\mathrm{V}_{\mathrm{H}} 3$-expressing cells. This was most obvious when comparing the 3-07 (12.56 aa), 1-69 (16.33 aa), and 4-34 (17.0 aa) genes. The 4-34 genes, furthermore, could be divided into two categories: those with CDR3 lengths longer than average (20.11) and those shorter than average
(12.33). When our $\operatorname{IgM}^{+}$cases were pooled with those available in GenBank/EMBL/DDBJ, these $\mathrm{V}_{\mathrm{H}}$ family-related hierarchies of CDR3 length were just as apparent and, in some instances, reached statistical significance (e.g., 3-07 versus 1-69: $P<0.05)$. In most cases, the short CDR3 segments of the $\mathrm{V}_{\mathrm{H}} 3$ group and the shorter $\mathrm{V}_{\mathrm{H}} 4-34$ subgroup contained a $\mathrm{J}_{\mathrm{H}} 4$ segment, whereas the $\mathrm{V}_{\mathrm{H}} 1$ group and the longer 4-34 subgroup contained a $\mathrm{J}_{\mathrm{H}} 6$ or $\mathrm{J}_{\mathrm{H}} 5$ segment.

Second, members of the $\mathrm{V}_{\mathrm{H}} 1$ family frequently contained long stretches of tyrosines coded for by the $\mathrm{J}_{\mathrm{H}} 6$ segment that were only minimally somatically altered. This was in contrast to most B-CLL cells using $\mathrm{V}_{\mathrm{H}} 3$ genes and certain B-CLL cells using $\mathrm{V}_{\mathrm{H}} 4$ genes, which had shorter CDR3 that frequently used a significantly altered $\mathrm{J}_{\mathrm{H}} 4$ gene.

Finally, these differences in $\mathrm{J}_{\mathrm{H}}$ gene association resulted in a $V_{H}$ family-related hierarchy in charge $\left(V_{H} 1, V_{H} 4\right.$, and $\left.V_{H} 3\right)$ that, again, was most easily recognized by inspecting the $\mathrm{V}_{\mathrm{H}}$ 1-69 (pI: 3.53), 4-34 (pI: 4.37), and 3-07 (pI: 5.89) genes of the $\mathrm{IgM}^{+}$group. Among the non-IgM ${ }^{+}$group, CDR3 charge was much less acidic, often exceeding a value of 5.50.

We believe that these $\mathrm{V}_{\mathrm{H}}$ family- and gene-related differences in HCDR3 reflect selection for specific structural motifs that facilitate antigen binding. If so, many more than $20 \%$ of the $\mathrm{IgM}^{+} \mathrm{B}-\mathrm{CLL}$ cells would have been selected for antigen binding. However, the stage(s) of B cell development at which these selections occur is not clear at this point.

Receptor prototypes. Taken together, these studies suggest prototypic rearranged $\mathrm{H}$ chain variable region genes in B-CLL cells (Fig. 4). Thus, $\mathrm{V}_{\mathrm{H}} 1$ sequences, exemplified by the 1-69-expressing B-CLL cells, remain predominantly unmutated and frequently associated with D3 (3-3) and $\mathrm{J}_{\mathrm{H}} 6$ segments. This results in a highly acidic HCDR3 that is slightly longer than the average. $\mathrm{V}_{\mathrm{H}} 3$ sequences, exemplified by the 3-07-expressing B-CLLs, frequently accumulate numerous mutations and associate with $\mathrm{D} 3$ and $\mathrm{J}_{\mathrm{H}} 4$ genes. These receptors have a CDR3 that is shorter and considerably less acidic than the $\mathrm{V}_{\mathrm{H}} 1$ prototype. Finally, $\mathrm{V}_{\mathrm{H}} 4$ sequences, exemplified by the 4-34-expressing CLLs, accumulate mutations in $~ 50 \%$ of the cases. Because these receptors use either a $\mathrm{J}_{\mathrm{H}} 4$ or $\mathrm{J}_{\mathrm{H}} 6$ gene, their CDR3 are either shorter, like the $\mathrm{V}_{\mathrm{H}} 3$ group, or longer, like the $\mathrm{V}_{\mathrm{H}} 1$ group. In addition, they tend to be slightly less acidic than the $\mathrm{V}_{\mathrm{H}} 1$ group.

It is unclear at this juncture whether these prototypes represent features unique to B-CLL cells or are shared with $\mathrm{B}$ cells of the normal adult or aging repertoire. Although we have been able to collect data on 188 B-CLL cases by combining our data with those in published articles and in GenBank/ EMBL/DDBJ (21, 30-38), a coordinated compilation of both B-CLL gene sequences and normal $B$ cell subset sequences will permit more definitive answers to these questions.

Maturation stage(s) of B-CLL cells. Finally, based on the presence of somatic mutations, it seems incontrovertible that $\sim 50 \%$ of $\operatorname{IgM}^{+}$B-CLL cells and $\sim 75 \%$ of non-IgM ${ }^{+}$cells have been previously stimulated by antigen. Therefore, these cells should be considered "experienced" or "memory" $\mathrm{CD}^{+} \mathrm{B}$ cell progeny. This conclusion is in line with those of Schroeder and Dighiero, who previously compared the sequences of a series of B-CLL cases (21), and with the observations that $\operatorname{IgM}^{+}$B-CLL cells can undergo intraclonal isotype class switching (61-64), a process that suggests clonal maturation.

However, what about those B-CLL cells that do not display $\mathrm{V}_{\mathrm{H}}$ gene mutations? Should these be considered virgin $\mathrm{B}$ cells 


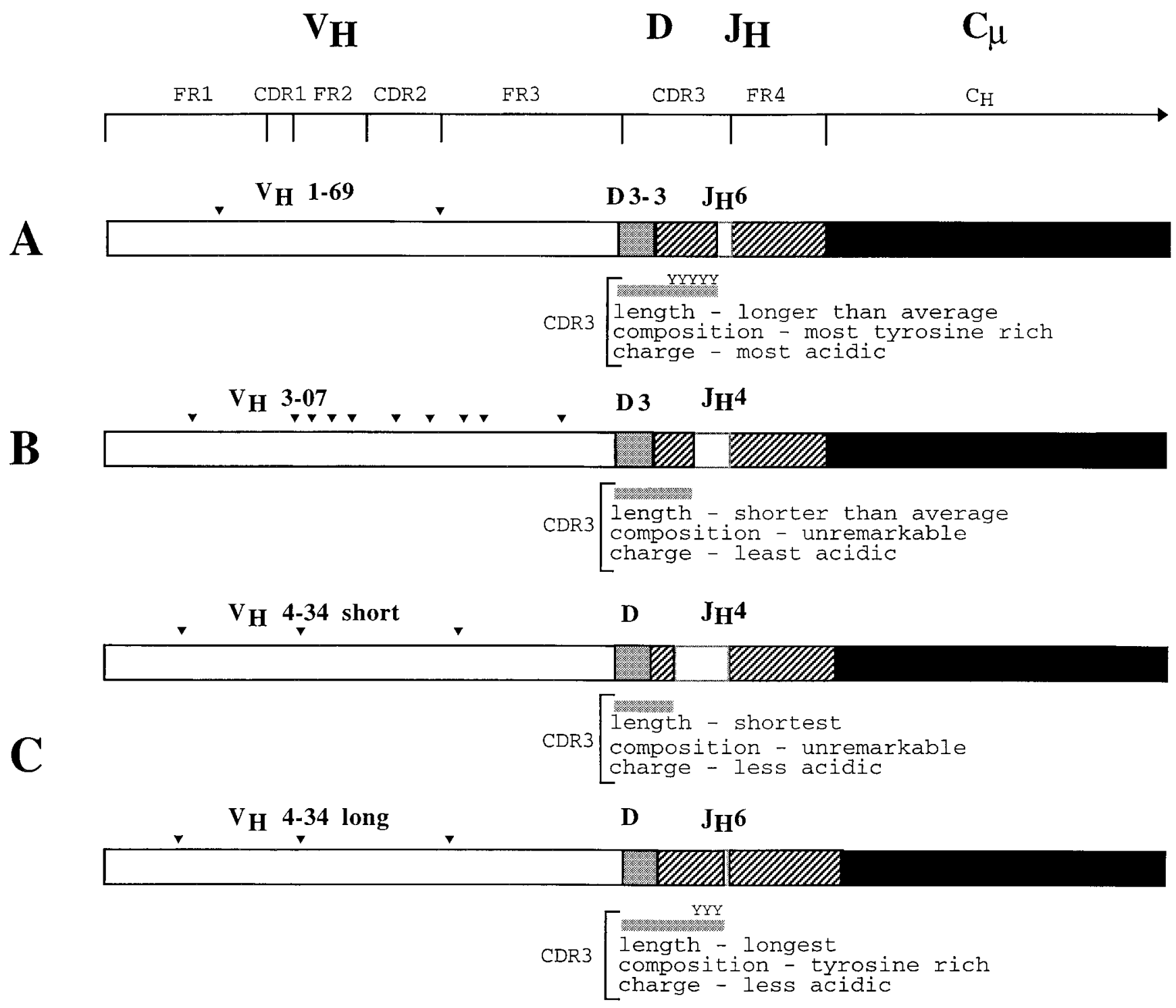

Figure 4. Prototypic variable regions of surface membrane IgM receptors in B-CLL. Schematic representations of the proposed $\mathrm{V}_{\mathrm{H}} 1-69(A)$, $\mathrm{V}_{\mathrm{H}}$ 3-07 (B), and $\mathrm{V}_{\mathrm{H}}$ 4-34 $(C)$ prototypic $\mathrm{V}$ regions. Arrowheads represent possible mutations. See Discussion for details.

or B cells driven by antigens that cannot induce somatic mutations (e.g., autoantigens) or antigens that select for unmutated $\mathrm{V}_{\mathrm{H}}$ sequences (e.g., superantigens) and/or distinct CDR3 characteristics (certain exo- or autoantigens)? Based on the overuse of specific $\mathrm{V}_{\mathrm{H}}, \mathrm{D}$, and $\mathrm{J}_{\mathrm{H}}$ genes, and the apparent constraints on HCDR3 structure, we favor the hypothesis that these cells also have been antigen driven and represent memory cells. However, we cannot eliminate the possibility that these receptor restrictions are developmental and represent selections that have occurred before exiting the bone marrow, thus making these virgin B cells with albeit developmentally restricted receptor structures.

\section{Acknowledgments}

We thank Cristina Sison and Martin Lesser for their help in the statistical analyses and Charles Chu and Peter K. Gregersen for their critical review of the manuscript.
These studies were supported in part by U.S. Public Health Service grants AI 10811 (N. Chiorazzi) and AI 33621 (H.W. Schroeder, Jr.), the Joseph Eletto Leukemia Research Fund, the Jean Walton Fund for Lymphoma \& Myeloma Research, the Richard and Nancy Leeds Fund of the Department of Medicine of North Shore University Hospital, and the Associazione Italiana per la Ricerca sul Cancro.

\section{References}

1. Yancopoulos, G.D., S.V. Desiderio, M. Paskind, J.F. Kearney, D. Baltimore, and F.W. Alt. 1984. Preferential utilization of the most J-proximal $\mathrm{V}_{\mathrm{H}}$ gene segments in pre-B cell lines. Nature. 311:727-733.

2. Perlmutter, R.M., J.F. Kearney, S.P. Chang, and L.E. Hood. 1985. Developmentally controlled expression of immunoglobulin $\mathrm{V}_{\mathrm{H}}$ genes. Science. 227: 1597-1601.

3. Schroeder, H.W., Jr., J.L. Hillson, and R.M. Perlmutter. 1987. Early restriction of the human antibody repertoire. Science. 238:791-793.

4. Suzuki, I., L. Pfister, A. Glas, C. Nottenburg, and E.C.B. Milner. 1995. Representation of rearranged $\mathrm{V}_{\mathrm{H}}$ gene segments in the human adult antibody repertoire. J. Immunol. 154:3902-3911.

5. Hillson, J.L., I.R. Oppliger, E.H. Sasso, E.C.B. Milner, and M.H. Wener. 
1992. Emerging human B cell repertoire. Influence of developmental stage and interindividual variation. J. Immunol. 149:3741-3752.

6. Kraj, P., S.P. Rao, A.M. Glas, R.R. Hardy, E.C. Milner, and L.E. Silberstein. 1997. The human heavy chain Ig V region gene repertoire is biased at all stages of B cell ontogeny, including early pre-B cells. J. Immunol. 158:58245832 .

7. Pascual, V., Y-J. Liu, A. Magalski, O. de Bouteiller, J. Banchereau, and J.D. Capra. 1994. Analysis of somatic mutations in five B cell subsets of human tonsil. J. Exp. Med. 180:329-339.

8. Casali, P., M.T. Kasaian, and G. Haughton. 1994. B-1 (CD5) cells. In Autoimmunity: Physiology and Disease. A. Coutinho and M.D. Kazatchkine, editors. John Wiley and Sons, Inc. New York. 57-88.

9. Hardy, R.R., and K. Hayakawa. 1992. Developmental origins, specificities and immunoglobulin gene biases of murine Ly-1 B cells. Intern. Rev. Immunol. 8:189-207.

10. Kipps, T.J., E. Tomhave, P.P. Chen, and D.A. Carson. 1988. Autoantibody-associated $\kappa$ light chain variable region gene expressed in chronic lymphocytic leukemia with little or no somatic mutation. Implications for etiology and immunotherapy. J. Exp. Med. 167:840-852.

11. Meeker, T.C., J.C. Grimaldi, R. O'Rourke, J. Loeb, G. Juliusson, and S. Einhorn. 1988. Lack of detectable somatic hypermutation in the $\mathrm{V}$ region of the Ig $\mathrm{H}$ chain gene of a human chronic B lymphocytic leukemia. J. Immunol. 141: 3994-3998.

12. Pratt, L.F., L. Rassenti, J. Larrick, B. Robbins, P.M. Banks, and T.J. Kipps. 1989. Ig V region gene expression in small lymphocytic lymphoma with little or no somatic hypermutation. J. Immunol. 143:699-705.

13. Deane, M., and J.D. Norton. 1990. Immunoglobulin heavy chain variable region family usage is independent of tumor cell phenotype in human B lineage leukemias. Eur. J. Immunol. 20:2209-2217.

14. Kuppers, R., A. Gause, and K. Rajewsky. 1991. B cells of chronic lymphatic leukemia express V genes in unmutated form. Leuk. Res. 15:487-496.

15. Friedman, D.F., J.S. Moore, J. Erikson, J. Manz, J. Goldman, P.C. Nowell, and L.E. Silberstein. 1992. Variable region gene analysis of an isotypeswitched (IgA) variant of chronic lymphocytic leukemia. Blood. 80:2287-2297.

16. Wagner, S.D., and L. Luzzatto. 1993. $\mathrm{V}_{\mathrm{k}}$ gene segments rearranged in chronic lymphocytic leukemia are distributed over a large portion of the $\mathrm{V}_{\mathrm{k}}$ locus and do not show somatic mutation. Eur. J. Immunol. 23:391-397.

17. Stevenson, F.K., M.B. Spellerberg, J. Treasure, C.J. Chapman, L.E. Silberstein, T.J. Hamblin, and D.B. Jones. 1993. Differential usage of an Ig heavy chain variable region gene by human B cell tumors. Blood. 82:224-230.

18. Cai, J., C. Humphries, A. Richardson, and P.W. Tucker. 1992. Extensive and selective mutation of a rearranged $\mathrm{V}_{\mathrm{H}} 5$ gene in human $\mathrm{B}$ cell chronic lymphocytic leukemia. J. Exp. Med. 176:1073-1081.

19. Hashimoto, S., M. Wakai, J. Silver, and N. Chiorazzi. 1992. Biased usage of variable and constant region genes by $\mathrm{IgG}^{+}, \mathrm{CD}^{+}$human leukemic B cells. NY Acad. Sci. 651:477-479.

20. Ebeling, S.B., M.E.M. Schutte, and T. Logtenberg. 1993. Molecular analysis of $\mathrm{V}_{\mathrm{H}}$ and $\mathrm{V}_{\mathrm{L}}$ regions expressed in IgG-bearing chronic lymphocytic leukemia (CLL): further evidence that CLL is a heterogenous group of tumors. Blood. 82:1626-1631.

21. Schroeder, H.W., and G. Dighiero. 1994. Clues to the pathogenesis of CLL through analysis of B cell CLL antibody repertoires. Immunol. Today. 15: 288-294.

22. Hashimoto, S., M. Dono, M. Wakai, S.L. Allen, S.M. Lichtman, P. Schulman, V.P. Vinciguerra, M. Ferrarini, J. Silver, and N. Chiorazzi. 1995. Somatic diversification and selection of immunoglobulin heavy and light chain variable region genes in $\mathrm{IgG}^{+} \mathrm{CD}^{+}$chronic lymphocytic leukemia B cells. $J$. Exp. Med. 181:1507-1517.

23. Rassenti, L.Z., and T.J. Kipps. 1997. Lack of allelic exclusion in B cell chronic lymphocytic leukemia. J. Exp. Med. 185:1435-1445.

24. Rassenti, L.Z., H. Kohsaka, and T.J. Kipps. 1995. Analysis of immunoglobulin $\mathrm{V}_{\mathrm{H}}$ gene repertoire by an anchored PCR-ELISA. Ann. NY Acad. Sci. 764:463-473.

25. Tomlinson, I.M., S.C. Williams, S.J. Corbett, J.B.L. Cox, G. Winter. 1996. V BASE sequence directory. MRC Centre for Protein Engineering, Cambridge, UK.

26. Chang, B., and P. Casali. 1994. The CDR1 sequences of a major proportion of human germline $\mathrm{Ig} \mathrm{V}_{\mathrm{H}}$ genes are inherently susceptible to amino acid replacement. Immunol. Today. 15:367-373.

27. Corbett, S.J., I.M. Tomlinson, E.L.L. Sonnhammer, D. Buck, and G. Winter. 1997. Sequence of the human immunoglobulin diversity (D) segment locus: a systematic analysis provides no evidence for the use of DIR segments, inverted D segments, "minor" D segments or D-D recombination. J. Mol. Biol. 270:587-597.

28. Raaphorst, F.M., C.S. Raman, J. Tami, M. Fischbach, and I. Sanz. 1997. Human Ig heavy chain CDR3 regions in adult bone marrow pre-B cells display an adult phenotype of diversity: evidence for structural selection of $\mathrm{D}_{\mathrm{H}}$ amino acid sequences. Int. Immunol. 9:1503-1515.

29. Shin, E.K., F. Matsuda, H. Nagaoka, Y. Fukita, T. Imai, K. Yokoyama, E. Soeda, and T. Honjo. 1991. Physical map of the $3^{\prime}$ region of the human immunoglobulin heavy chain locus: clustering of autoantibody-related variable segments in one haplotype. EMBO (Eur. Mol. Biol. Organ.) J. 10:3641-3645.
30. Shen A, C. Humphries, P. Tucker, and F. Blattner. 1987. Human heavychain variable region gene family nonrandomly rearranged in familial chronic lymphocytic leukemia. Proc. Natl. Acad. Sci. USA. 84:8563-8567.

31. Kipps, T., E. Tomhave, L.F. Pratt, S. Duffy, P.P. Chen, and D.A. Carson. 1989. Developmentally restricted immunoglobulin heavy chain variable region gene expressed at high frequency in chronic lymphocytic leukemia. Proc. Natl. Acad. Sci. USA. 86:5913-5917.

32. Spatz, L.A., K.K. Wong, M. Williams, R. Desai, J. Golier, J.E. Berman, F.W. Alt, and N. Latov. 1990. Cloning and sequence analysis of the $V_{H}$ and $V_{L}$ regions of an anti-myelin/DNA antibody from a patient with peripheral neuropathy and chronic lymphocytic leukemia. J. Immunol. 144:2821-2828.

33. Friedman, D.F., E.A. Cho, J. Goldman, C.E. Carmak, E.C. Besa, R.R Hardy, and L.E. Silberstein. 1991. The role of clonal selection in the pathogenesis of an autoreactive human B cell lymphoma. J. Exp. Med. 174:525-537.

34. Matolcsy, A., P. Casali, R.G. Nador, Y.F. Liu, and D.M. Knowles. 1997. Molecular characterization of IgA- and/or IgG-switched chronic lymphocytic leukemia B cells. Blood. 89:1732-1739.

35. Cherepakhin V., S.M. Baird, G.W. Meisenholder, and T.J. Kipps. 1993. Common clonal origin of chronic lymphocytic leukemia and high-grade lymphoma of Richter's syndrome. Blood. 82:3141-3147.

36. Korganow, A.S., T. Martin, J.C. Weber, B. Lioure, P. Lutz, A.M Knapp, and J.L. Pasquali. 1994. Molecular analysis of rearranged $V_{H}$ genes during B cell chronic lymphocytic leukemia: intraclonal stability is frequent but not constant. Leuk. Lymphoma. 14:55-69.

37. Ikematsu W., H. Ikematsu, T. Otsuka, S. Okamura, S. Kashiwagi, and Y. Niha. 1995. Surface phenotype and immunoglobulin heavy chain gene usage in chronic B cell leukemias. Ann. NY Acad. Sci. 764:492-495.

38. Foroni, L., A. Werner, M. Papaioannou, J. Yaxley, M. Attard, and A.V. Hoffbrand. 1996. The $\mathrm{V}_{\mathrm{H}}$ usage in B cell chronic lymphocytic leukemia cells is a random event and it is not disease related. Blood. 88:238. (Abst.)

39. Brezinschek, H-P., S.J. Foster, R.I. Brezinschek, T. Dorner, R. DomiatiSaad, and P.E. Lipsky. 1997. Analysis of the human $V_{H}$ gene repertoire. Differential effects of selection and somatic hypermutation on human peripheral $\mathrm{CD}^{+} / \mathrm{IgM}^{+}$and $\mathrm{CD}^{-} / \mathrm{IgM}^{+}$B cells. J. Clin. Invest. 99:2488-2501.

40. Stevenson, F.K., M.B. Spellerberg, C.J. Chaplin, and T.J. Hamblin. 1995. Differential usage of an autoantibody-associated $V_{H}$ gene, $V_{H} 4-21$, by human B cell tumors. Leuk. Lymphoma. 16:379-384.

41. Kipps, T. 1993. Immunoglobulin genes in chronic lymphocytic leukemia. Blood Cells. 19:615-625.

42. Silberstein, L.E., L.C. Jefferies, J. Goldman, D. Friedman, J.S. Moore, P.C. Nowell, D. Roelcke, W. Pruzanski, J. Roudier, and G.J. Silverman. 1991 Variable region gene analysis of pathologic human autoantibodies to the related i and I red blood cell antigens. Blood. 78:2372-2386.

43. Pascual, V., K. Victor, D. Lelsz, M.B. Spellerberg, T.J. Hamblin, K.M. Thompson, I. Randen, J. Natvig, J.D. Capra, and F.K. Stevenson. 1991. Nucleotide sequence analysis of the $\mathrm{V}$ regions of two IgM cold agglutinins. Evidence that the $\mathrm{V}_{\mathrm{H}}$ 4-21 gene segment is responsible for the major cross-reactive idiotype. J. Immunol. 146:4385-4391.

44. Leoni, J., J. Ghiso, F. Goni, and B. Frangione. 1991. The primary structure of the Fab fragment of protein KAU, a monoclonal immunoglobulin $\mathrm{M}$ cold agglutinin. J. Biol. Chem. 266:2836-2842.

45. Hsu, F.J., and R. Levy. 1995. Preferential use of the $\mathrm{V}_{\mathrm{H}} 4 \mathrm{Ig}$ gene family by diffuse large cell lymphoma. Blood. 86:3072-3082.

46. Pascual, V., and J.D. Capra. 1992. $\mathrm{V}_{\mathrm{H}} 4-21$, a human $\mathrm{V}_{\mathrm{H}}$ gene segment overrepresented in the autoimmune repertoire. Arthritis Rheum. 35:11-18.

47. Rettig, M.B., R.A. Vescio, J. Cao, C.H. Wu, J.C. Lee, E. Han, M. DerDanielian, R. Newman, C. Hong, A.K. Lichtenstein, and J.R. Berenson. 1996. $\mathrm{V}_{\mathrm{H}}$ gene usage in multiple myeloma: complete absence of the $\mathrm{V}_{\mathrm{H}} 4-21\left(\mathrm{~V}_{\mathrm{H}} 4-34\right)$ gene. Blood. 87:2846-2852.

48. Johnson, T.A., L.Z. Rassenti, and T.J. Kipps. 1997. $\mathrm{V}_{\mathrm{H}} 1$ genes expressed in B cell chronic lymphocytic leukemia exhibit distinctive molecular features. $J$. Immunol. 158:235-246.

49. Sasso, E.H., T. Johnson, and T.J. Kipps. 1996. Expression of the immunoglobulin $\mathrm{V}_{\mathrm{H}}$ gene $51 \mathrm{p} 1$ is proportional to its germline gene copy number. $J$. Clin Invest. 97:2074-2080.

50. Stewart, A.K., C. Huang, B.D. Stollar, and R.R. Schwartz. 1993. Highfrequency representation of a single $\mathrm{V}_{\mathrm{H}}$ gene in the expressed human $\mathrm{B}$ cell repertoire. J. Exp. Med. 177:409-418.

51. Milner, E.C.B., W.O. Hufnagle, A.M. Glas, I. Suzuki, and C. Alexander. 1995. Polymorphism and utilization of human $\mathrm{V}_{\mathrm{H}}$ genes. Ann. NY Acad. Sci. 764:50-61.

52. Jukes, T.H., and J.L. King. 1979. Evolutionary nucleotide replacements in DNA. Nature. 281:605-606.

53. Shlomchik, M.J., A. Marshak-Rothstein, C.B. Wolfowicz, T.L. Rothstein, and M.G. Weigert. 1987. The role of clonal selection and somatic mutation in autoimmunity. Nature. 328:805-811.

54. Rudikoff, S., A.M. Giusti, W.D. Cook, and M.D. Scharff. 1982. Single amino acid substitution altering antigen-binding specificity. Proc. Natl. Acad. Sci. USA. 79:1979-1983.

55. Jeske, D.J., J. Jarvis, C. Milstein, J.D. Capra. 1984. Junctional diversity is essential to antibody activity. J. Immunol. 133:1090-1092.

56. Kussie, P.H., B. Parhami-Seren, L.J. Wysocki, and M.N. Margolies. 
1994. A single engineered amino acid substitution changes antibody fine specificity. J. Immunol. 152:146-152.

57. Katz, J.B., W. Limpanasithikul, and B. Diamond. 1994. Mutational analysis of an autoantibody: differential binding and pathogenicity. J. Exp. Med. 180:925-932.

58. Hillson, J., N.S. Karr, I.R. Oppliger, M. Mannik, and E.H. Sasso. 1993. The structural basis of germline-encoded $\mathrm{V}_{\mathrm{H}} 3$ immunoglobulin binding to Staphylococcal protein A. J. Exp. Med. 178:331-336.

59. Silverman, G.J., R. Pires, and J.P. Bouvet. 1996. An endogenous sialoprotein and a bacterial $B$ cell superantigen compete with their $V_{H}$ family-specific binding interactions with human Igs. J. Immunol. 157:4496-4502.

60. Lam, K.P., R. Kuhn, and K. Rajewsky. 1997. In vivo ablation of surface immunoglobulin on mature B cells by inducible targeting results in rapid cell death. Cell. 90:1073-1083.

61. Dono, M., S. Hashimoto, F. Fais, V. Trejo, S.L. Allen, S.M. Lichtman, P. Schulman, V.P. Vinciguerra, B. Sellars, P.K. Gregersen, M. Ferrarini, and N.
Chiorazzi. 1996. Evidence for progenitors of chronic lymphocytic leukemia B cells that undergo intraclonal differentiation and diversification. Blood. 87: 1586-1594.

62. Malisan, F., A-C. Fluckiger, S. Ho, C. Guret, J. Banchereau, and H. Martinez-Valdez. 1996. B-chronic lymphocytic leukemia can undergo isotype class switching in vivo and can be induced to differentiate and switch in vitro. Blood. 87:717-724.

63. Efremov, D.G., M. Ivanovski, F.D. Batista, G. Pozzato, and O. Burrone 1996. IgM-producing chronic lymphocytic leukemia cells undergo immunoglobulin isotype-switching without acquiring somatic mutations. J. Clin. Invest. 98: 290-298.

64. Fais, F., B. Sellars, F. Ghiotto, X-J. Yan, M. Dono, S.L. Allen, D. Budman, K. Dittmar, J. Kolitz, S.M. Lichtman, et al. 1996. Examples of in vivo isotype class switching of $\operatorname{IgM}^{+}$chronic lymphocytic leukemia B cells. J. Clin. Invest. 98:1659-1666. 